\title{
Our Schools are No Longer Safe: The Narratives of Educators at Peri-Urban High Schools in Umlazi, KwaZulu-Natal, South Africa
}

\author{
Oluwatobi Joseph Alabi \\ ORCID iD: https://orcid.org/0000-0003-1220-760X
}

\section{Thandanani Ngidi \\ ORCID iD: https://orcid.org/0000-0002-3382-7421}

\section{Abstract}

The intensifying rate of school-based violence in South Africa has become a major concern for school management, non-governmental organisations and the government at large. The constant disruption of knowledge dissemination because of upheavals and conflicts within spaces of learning has diminished the value of education and threatened the peace and serenity of South African schools. Educators and learners alike are in constant fear for their lives and wellbeing whenever they are on some of these school premises. This paper argues that the escalating nature of school-based violence in South Africa cannot be divorced from the historical experiences of conflict and aggression as a form of resistance that were prevalent within the country during the time of apartheid. It is also important to note that violence within learning spaces in South Africa reflects the current prevalence of criminality within the country post-apartheid. This paper, through a qualitative approach, engaged 15 educators on their experiences of school-based violence in one of the most violent neighbourhoods in South Africa (Umlazi). It became evident that this menace has affected learning process and has grave educational, social, and psychological implications on learners and educators. The study therefore recommends that a combined approach, involving all stakeholders and institutions within the society, is required to curb the growing spate of school 
violence. Government and stakeholders must take the issue very seriously, as its effects spread across the board and impact on the productivity and attrition rates.

\section{Introduction}

Violence in schools has been reported to be a global phenomenon, and without exception a major concern for government and educational stakeholders in South Africa. UNESCO (2017) reports that 246 million children the world over are annually affected by school-based violence. Violence in schools within South Africa is a constitutional violation of learners' rights to 'freedom and security' (Constitution of the Republic of South Africa, Act 108 of 1996), and a violation of the right to basic education. The Centre for Justice and Crime Prevention (2016: 5) defines school violence as,

any acts of violence that take place inside an educational institution, when travelling to and from school or a school-related event, or during such an event. These school-based acts of violence can be both physical and non-physical and may or may not result in bodily or emotional harm to the victim. This violence typically takes the form of learner-on-learner, learner-on-educator, educator-on-educator, and educator-on-learner violence and severely disrupts the normal functioning of the schooling system.

As school-based violence remains a major problem in South Africa (Ncontsa $\&$ Shumba 2013), its implications on learning processes and the experiences of educators and learners are daunting. Fiske et al. (2012) note that the principal functions of schools include knowledge dissemination, providing socio-emotional support and integrating learners into communities. On the contrary, the heightening spate of violence in South African schools has threatened the effective realisation of these functions which the school is expected to achieve. Stevens, Wyngaardt and Van Niekerk (2001) argue that violence within school environments disrupts the essential function of transmitting knowledge. The implications of unrest within schools is that it instils fear in both educators and learners, distracts the learning process, and impacts negatively on the education system (Prinsloo 2008; Van Jaarsveld 


\section{Oluwatobi Joseph Alabi \& Thandanani Ngidi}

2008; Ncontsa \& Shumba 2013; Banks 2014; Liang, Flisher \& Lombard 2007). According to Van Jaarsveld (2008), parents believe that their children are in a safe place and under the protection of educators, but how realistic is this when violence within these schools is not just a threat to learners, but also to educators? The South African Institute for Racial Relations reports that South Africa has the most dangerous schools in the world, and learners and educators do not feel safe at school (Burton \& Leoschut 2013).

School violence in South Africa has gained a lot of attention both in the mainstream media and in academia. Recently more awareness has been raised regarding the severity of school violence as a major crisis that has to be dealt with due to the increase in the number of videos on school-based assault trending on social media platforms and various news feeds. It is important to note that the media often focus on the explicit details of violent incidents in schools and capitalise on the sensation these incidents create. Very rarely do they focus on the vulnerability of the educators to cope with the overflow of violent symptoms from society into schools. A search through scholarly literature reveals that the impact and the experience of this violence on learners have been well investigated (Prinsloo 2008; Ncontsa \& Shumba 2013; Simpson 1993; Barbarin \& Richter 2001; Dawes, Tredoux \& Feinstein 1989; Neser 2006; Shields, Nadasen \& Pierce 2008; Ngqela \& Lewis 2012; Mathews \& Benvenuti 2014), but there are very limited studies that have examined educators' narratives of this violence (Du Plessis 2008; Bester \& Du Plessis 2010; De Wet 2010; Taole \& Ramorola 2014, Shields, Nadasen \& Hanneke 2015). Bringing educators' narratives to the discourse of schools-based violence in South Africa will bring to the fore the dynamics of the nature of the violence in South African schools. It will highlight why educators perpetuate violence, or what exposes them, as well as various strategies they adopt in managing violence within the school environment. In the development of an effective framework to address school-based violence in South Africa, it is important to know how educators conceptualise this violence, how these disruptions affect them, and their immediate response to the violence. This paper, therefore, provides narratives of educators on school-based violence at selected periurban high schools in Umlazi. Experience is a broad concept that incorporates incidents, educators' perceptions and the personalised meanings derived from the experiences of violence in an educational setting. Du Plessis' (2008:4) description of experience is an important conceptual tool that guided how this paper understood and engaged the participants' narratives. Du Plessis notes 
that experience entails a conscious event, as opposed to an imagined scenario and must have resulted from some sort of learning. Adopting experience as a conceptual tool aided the interpretation of educators' narratives as a lived phenomenon. It also helped to understand how educators conceptualise violence, as well as how they develop coping and management strategies.

\section{Methodology}

This study adopted an interpretive qualitative design. As a study aimed at exploring educators' narratives of school violence, it is indicative that the research adopts a design that will allow for the investigation of diverse realities and the emergence of various narrative as described by the educators. In this regard, Mouton (2001) explains that a research design allows for the answering of a research question in an explorative and descriptive manner. The interpretive paradigm allowed the researchers to unpack and understand the feelings, social situations, experience, and phenomenon of violence as it occurs in the 'real world' of educators. Moreover, one of the strengths of the inter-pretive paradigm is to 'explain data within a certain context' (Terre Blanche \& Kelly 1999: 127). The underlying knowledge of interpretivism is to understand the experiences of individuals within a certain context and to comprehend the subjective meanings attached to them (Schwandt 2014). Hence, the researchers attempted to gain an insider's perspective into educators' experiences of violence in peri-urban Umlazi high schools. Unstructured interviews was the tool of data collection so as to obtain first-hand information from participants in the study.

A non-probability sampling technique was adopted to recruit participants. Creswell and Creswell (2017) define non-probability sampling as a process of selecting a sample without giving every member of a population an equal opportunity for selection. Purposive sampling, a variant of nonprobability sampling, was a major strategy for selection in this study. The researchers identified educators who met pre-defined characteristics and who are believed to be in the best position to give an appropriate response to the research questions. These previously defined characteristics were that the educator must be teaching at a secondary school located in Umlazi, have been working as an educator for no less than a year, and must have experienced school violence. A total of 15 educators were selected from the Ndukwenhle, Ogwini and Swelihle High Schools in Umlazi, Durban, South Africa. These 


\section{Oluwatobi Joseph Alabi \& Thandanani Ngidi}

schools were selected because they have a history of school violence and they provided access to the researchers. Moreover, thematic analysis, a recursive literature review, and member checking were used to enhance the reliability and quality of the data.

This study was approved by the University of KwaZulu-Natal Ethics Committee and a gatekeeper's permission was granted by the KwaZulu-Natal Provincial Department of Education. Following these approvals, the fieldwork was carried out between May and June 2018. With the aid of a semi-structured interview guide, the researchers painstakingly engaged participants in an indepth personal interview that lasted an average of about forty-five minutes each. The interviews were scheduled at the convenience of the educator, but were usually when they had free teaching slots. Before interviews commenced, the purpose of the interview was clearly outlined to participants and they voluntarily signed an informed consent form. They also consented to being audio-recorded; these recordings were vital to ensure that information was not lost in the process of transcribing.

\section{Data Analysis}

The findings discussed in this article were collated through a systemic theme generation process. The researchers immersed themselves in the voluminous interview transcripts, field notes, and observations to identify recurrent themes from the interviews. The themes were subsequently discussed to establish a connection between thematic concepts. The identification of common and recurrent patterns in the narratives of participants helped in the generation of themes for discussion. Member checking was used to ensure that the participants could verify that their thoughts were captured well and reported accurately during data interpretation. Transcriptions were shared with participants to ensure that their narratives were captured correctly and not misinterpreted. One of the advantages of member checking is to ensure that narratives are not misconstrued in the process of transcription.

The data analysis was a continuous process that started with the preliminary meeting and conversation with participants. A preliminary meeting with all educators took place a week before data collection officially commenced. After securing ethical clearance permission, upon receipt of a gatekeeper's permission, the researchers proceeded to the schools to meet with the administrators and staff. This allowed the researchers to identify and 
eliminate potential participants who might not possess adequate experience about the study aim. All interviews were studied several times in conjunction with observed non-verbal cues given by participants. The field notes were extremely useful during data interpretation as they helped to divide the data into themes. Concurrently, the field notes were compared with the transcribed audios to ensure data quality and accuracy. This also allowed the researchers to constantly compare different themes for possible patterns for categorisation. To ensure effective data control, the researchers ensured that, firstly, the participants verified the reported data to ensure that the meanings had not been misinterpreted/misrepresented or taken out of context. Secondly, in the process of analysing and discussing the findings from the study, a comparative approach with relevant literature was made to identify areas in which the findings support or dispute arguments in literature. In cases of discrepancies with existing literature, findings were verified further to ensure that the argument emanated entirely from the study.

\section{Table 1: A Summary of the Essential Themes that Emanated from the Research}

\begin{tabular}{|l|l|l|}
\hline $\begin{array}{c}\text { Category: } \\
\text { Causes of School } \\
\text { Violence }\end{array}$ & $\begin{array}{l}\text { Contextualisation of verbatim } \\
\text { data }\end{array}$ & $\begin{array}{c}\text { Verbatim quotes from } \\
\text { the interviews }\end{array}$ \\
\hline $\begin{array}{l}\text { Subcategory: } \\
\text { Destabilised } \\
\text { family system }\end{array}$ & $\begin{array}{l}\text { Participants opined that the } \\
\text { changing nature of the family is } \\
\text { a major contributor to the } \\
\text { escalation of school-based } \\
\text { violence across South African } \\
\text { schools. They believe that in } \\
\text { the traditional family system, } \\
\text { the father and mother figures } \\
\text { performed certain functions in } \\
\text { the effective upbringing of a } \\
\text { child, however, with the result } \\
\text { of various socio-cultural, global } \\
\text { and health-related issues that } \\
\text { have impacted on the family, } \\
\text { several learners now come from }\end{array}$ & $\begin{array}{l}\text { 'As educators, our roles } \\
\text { Some of these kids come } \\
\text { from homes where they } \\
\text { have one or no parent at } \\
\text { all. Most times their } \\
\text { family do not take up the } \\
\text { role of correcting bad } \\
\text { behaviour, as a result we } \\
\text { are confronted with } \\
\text { having to do their work of } \\
\text { disciplining these children } \\
\text { for them. Now the } \\
\text { problem is, kids that don't } \\
\text { get scolded at home will }\end{array}$ \\
\hline
\end{tabular}




\begin{tabular}{|c|c|c|}
\hline $\begin{array}{l}\text { Lack of support } \\
\text { from parents }\end{array}$ & $\begin{array}{l}\text { a single-headed family where } \\
\text { the head of the family is mainly } \\
\text { preoccupied with providing } \\
\text { economic resources, as opposed } \\
\text { to paying attention to the } \\
\text { behavioural attributes of the } \\
\text { child. } \\
\text { Most educators believe they do } \\
\text { not enjoy the required level of } \\
\text { the cooperation from parents } \\
\text { and guidance to instil discipline } \\
\text { in the learners. }\end{array}$ & $\begin{array}{l}\text { see their teachers as } \\
\text { wicked and might decide } \\
\text { to be confrontational. It is } \\
\text { things like this that } \\
\text { degenerate into violence'. } \\
\text { 'We become very careful } \\
\text { the way we discipline and } \\
\text { caution these kids because } \\
\text { it seems most parents are } \\
\text { not supportive. When the } \\
\text { child knows no matter } \\
\text { what he/she has done, the } \\
\text { parent will swing support } \\
\text { in their favour, they tend } \\
\text { to be very disrespectful, } \\
\text { talk back and disobey } \\
\text { instructions. By the time } \\
\text { you try to make them } \\
\text { conform, they incite their } \\
\text { colleagues and turn the } \\
\text { school into a war zone. } \\
\text { So, some parents are not } \\
\text { helpful'. }\end{array}$ \\
\hline $\begin{array}{l}\text { Subcategory: } \\
\text { Community } \\
\text { violence } \\
\text { modelling school- } \\
\text { based violence }\end{array}$ & $\begin{array}{l}\text { It is evident from the narratives } \\
\text { of the participants in this study } \\
\text { that the prevalent nature of } \\
\text { violence within South African } \\
\text { schools cannot be divorced } \\
\text { from the prevalence of violence } \\
\text { within the communities the } \\
\text { learners are part of. Most } \\
\text { learners reside in communities } \\
\text { and come from families where } \\
\text { violence has become a normal } \\
\text { mechanism for showing } \\
\text { discontent, dislike, and for }\end{array}$ & $\begin{array}{l}\text { 'Our country comes from } \\
\text { a very unique place in } \\
\text { history. During the } \\
\text { struggle to end apartheid, } \\
\text { a lot of our people had to } \\
\text { result in violent revolution } \\
\text { and as such it has spilt } \\
\text { into the present } \\
\text { democratic society where } \\
\text { we live. We must also } \\
\text { remember that this history } \\
\text { created a lot of inequality, } \\
\text { especially socio-economic }\end{array}$ \\
\hline
\end{tabular}




\begin{tabular}{|c|c|c|}
\hline & $\begin{array}{l}\text { resolving dispute and } \\
\text { difference. Hence, they have } \\
\text { become accustomed to the } \\
\text { violence and it spills into their } \\
\text { everyday life within the school } \\
\text { environment. Therefore, } \\
\text { addressing school violence } \\
\text { cannot be successful without } \\
\text { the cooperation of families and } \\
\text { communities. }\end{array}$ & $\begin{array}{l}\text { inequality and that being } \\
\text { said, a lot of non-white } \\
\text { folks are economically } \\
\text { challenged. How many } \\
\text { times have you heard of } \\
\text { school violence in a } \\
\text { predominantly white } \\
\text { school? So, these kids are } \\
\text { coming from homes that } \\
\text { are faced with the most } \\
\text { challenging situations and } \\
\text { from communities where } \\
\text { violence is still seen as a } \\
\text { perfect way to express } \\
\text { self. Learning is very } \\
\text { important, and kids are } \\
\text { very quick to pick up } \\
\text { some of these prevalent } \\
\text { norms within their } \\
\text { societies'. }\end{array}$ \\
\hline $\begin{array}{l}\text { Subcategory: } \\
\text { Gangsterism }\end{array}$ & $\begin{array}{l}\text { Every educator interviewed in } \\
\text { this study mentioned the } \\
\text { activities of gangs as the } \\
\text { incubating centres of school- } \\
\text { based violence. It is believed } \\
\text { that gang activities and rivalry } \\
\text { from outside the school } \\
\text { environment have spilt into the } \\
\text { schools and become the } \\
\text { pioneers of violence within } \\
\text { learning spaces. Hence, } \\
\text { sometimes the reason for } \\
\text { school-based violence might } \\
\text { not be connected to any specific } \\
\text { act that occurred within the } \\
\text { school but from the rivalry } \\
\text { between major gangs in the }\end{array}$ & $\begin{array}{l}\text { 'Most of these kids that } \\
\text { are members of gangs are } \\
\text { not the smartest of } \\
\text { learners, as such they are } \\
\text { more a liability to the } \\
\text { learning process. They } \\
\text { usually get caught up in } \\
\text { their gang-related } \\
\text { activities even when they } \\
\text { are in school, and over the } \\
\text { years, they have seized } \\
\text { sporting days as } \\
\text { opportunities to taunt } \\
\text { other learners they believe } \\
\text { are in opposition gangs. } \\
\text { This is not a good thing } \\
\text { for our schools, it is very } \\
\text { dangerous and [a] }\end{array}$ \\
\hline
\end{tabular}




\begin{tabular}{|l|l|l|}
\hline & $\begin{array}{l}\text { communities that have active } \\
\text { opposition members in schools. }\end{array}$ & $\begin{array}{l}\text { breeding ground for } \\
\text { school-based violence. } \\
\text { However, these gangs are } \\
\text { feeding on the broader } \\
\text { group based within their } \\
\text { communities'. }\end{array}$ \\
\hline $\begin{array}{l}\text { Subcategory: } \\
\text { consumption }\end{array}$ & $\begin{array}{l}\text { Learners who have exhibited } \\
\text { overly aggressive and unstable } \\
\text { behaviour have been reported } \\
\text { by other learners and some } \\
\text { educators to smell of liquor. It } \\
\text { is also evident from the } \\
\text { testimonies of some of their } \\
\text { colleagues as reported to } \\
\text { educators that they often } \\
\text { engage in the use of drugs. }\end{array}$ & $\begin{array}{l}\text { 'Our students report every } \\
\text { time other learners who } \\
\text { smell of liquor and use } \\
\text { drugs. They say they get } \\
\text { teased and shouted at by } \\
\text { these learners. It is also } \\
\text { some of these kids that } \\
\text { end up fighting } \\
\text { themselves and turning the } \\
\text { school into something } \\
\text { else'. }\end{array}$ \\
\hline $\begin{array}{l}\text { Subcategory: } \\
\text { Lack of } \\
\text { consequence } \\
\text { (Students doing } \\
\text { whatever they } \\
\text { want and getting } \\
\text { away with it) }\end{array}$ & $\begin{array}{l}\text { Most educators are of a strong } \\
\text { opinion that the lack of } \\
\text { consequences for the } \\
\text { inappropriate behaviour of the } \\
\text { violent offender is a motivation } \\
\text { for continued and further } \\
\text { perpetuation of violence within } \\
\text { the school environment. It is } \\
\text { becoming more evident that the } \\
\text { current measures to combat } \\
\text { violence are becoming less } \\
\text { effective and put educators in } \\
\text { harm's way. Most of the } \\
\text { educators believed that the } \\
\text { removal of corporal punishment } \\
\text { has been a major contributor to } \\
\text { school-based violence. Students } \\
\text { have become more } \\
\text { confrontational, rude, and }\end{array}$ & $\begin{array}{l}\text { 'I no longer report most } \\
\text { violent acts because I } \\
\text { know nothing will be done } \\
\text { and these learners are also } \\
\text { aware. It has reached a } \\
\text { point where you just have } \\
\text { react to be a big fool } \\
\text { before these kids. They } \\
\text { know [that] no matter } \\
\text { what they do, you're not } \\
\text { allowed to discipline them } \\
\text { in the form of punishment, } \\
\text { and they say it to your } \\
\text { face'. }\end{array}$ \\
\hline
\end{tabular}




\begin{tabular}{|c|c|c|}
\hline & $\begin{array}{l}\text { aggressive, and disregard } \\
\text { instruction because they know } \\
\text { they cannot be punished. It was } \\
\text { also noted that corporal } \\
\text { punishment might not be the } \\
\text { appropriate measure but not } \\
\text { proscribing specific punitive } \\
\text { consequences for learners and } \\
\text { perpetrators of violent } \\
\text { behaviour is highly } \\
\text { consequential and a demerit to } \\
\text { instilling discipline. }\end{array}$ & \\
\hline $\begin{array}{l}\text { Subcategory: } \\
\text { Inadequate } \\
\text { conflict } \\
\text { management } \\
\text { knowledge on the } \\
\text { part of educators }\end{array}$ & $\begin{array}{l}\text { Educators believe that } \\
\text { considering the nature of the } \\
\text { school and the disapproval of } \\
\text { corporal punishment, the } \\
\text { student has become more } \\
\text { disrespectful and as such } \\
\text { teachers must be very careful in } \\
\text { the way they manage their } \\
\text { classes and address potentially } \\
\text { dangerous situations that could } \\
\text { degenerate into school violence. } \\
\text { Conflict management skills are } \\
\text { essential in preventing school- } \\
\text { based violence, and where such } \\
\text { skills are lacking, violence } \\
\text { becomes prevalent. }\end{array}$ & $\begin{array}{l}\text { 'As teachers, we need to } \\
\text { be very vast in the way we } \\
\text { address some behaviour } \\
\text { that are potentials for } \\
\text { school violence. Most of } \\
\text { the things that have } \\
\text { degenerated into violence } \\
\text { having to do with an } \\
\text { altercation between the } \\
\text { teacher and learner are } \\
\text { because it has not been } \\
\text { properly managed. } \\
\text { Educators must be wise, } \\
\text { and you must be ready to } \\
\text { just let your ego down } \\
\text { sometimes understanding } \\
\text { these are kids and } \\
\text { avoiding violence'. }\end{array}$ \\
\hline $\begin{array}{l}\text { Category: } \\
\text { Nature of } \\
\text { Violence }\end{array}$ & & \\
\hline $\begin{array}{l}\text { Subcategory: } \\
\text { Prevalent }\end{array}$ & $\begin{array}{l}\text { Violence in its various forms is } \\
\text { generally regarded as prevalent }\end{array}$ & $\begin{array}{l}\text { 'Our schools are } \\
\text { becoming more terrible }\end{array}$ \\
\hline
\end{tabular}




\begin{tabular}{|c|c|c|}
\hline & $\begin{array}{l}\text { at the schools investigated. } \\
\text { Educators believe that, while } \\
\text { escalated forms of assault and } \\
\text { property destruction on the } \\
\text { decrease, there are more } \\
\text { insidious ways through which } \\
\text { learners assault one another and } \\
\text { victimise teachers. }\end{array}$ & $\begin{array}{l}\text { and this is very } \\
\text { worrisome. In all my years } \\
\text { as a teacher, it has never } \\
\text { gotten this worse. From } \\
\text { heightened indiscipline to } \\
\text { bullying, gang activities, } \\
\text { drug use, threatening both } \\
\text { learners and educators } \\
\text { with weapons, among } \\
\text { others. When we talk } \\
\text { about violence, they do } \\
\text { not need to burn down this } \\
\text { place before we feel } \\
\text { unsafe. It seems like the } \\
\text { rage in the learners of } \\
\text { these days is getting more } \\
\text { intense. They don't even } \\
\text { want to be corrected'. }\end{array}$ \\
\hline $\begin{array}{l}\text { Subcategory: } \\
\text { Educator directed } \\
\text { as much as to } \\
\text { learners. }\end{array}$ & $\begin{array}{l}\text { While participants opined that } \\
\text { the media and education } \\
\text { stakeholders, as well as society } \\
\text { at large, have always } \\
\text { understood school-based } \\
\text { violence as violence perpetrated } \\
\text { against learners by other } \\
\text { learners, or against learners by } \\
\text { educators; it is important to } \\
\text { begin to say that educators are } \\
\text { as much a victim as the } \\
\text { learners. Educators have } \\
\text { recently been victims of violent } \\
\text { acts at various high schools and } \\
\text { this is escalating and spreading. }\end{array}$ & $\begin{array}{l}\text { 'The following } \\
\text { indiscipline and trying to } \\
\text { make students conform } \\
\text { occur when educators are } \\
\text { caught in between. It } \\
\text { seems that, with every day } \\
\text { that goes by, more } \\
\text { educators become the } \\
\text { target of one or the other } \\
\text { attack. We are no longer } \\
\text { safe. Everyone must } \\
\text { realise school-based } \\
\text { violence is not only about } \\
\text { learners being victims } \\
\text { anymore, but teachers are } \\
\text { also victims'. }\end{array}$ \\
\hline Subcategory: & $\begin{array}{l}\text { Most participants narrate that } \\
\text { the nature of violence could be }\end{array}$ & $\begin{array}{l}\text { 'The prevalence of school- } \\
\text { based violence can be }\end{array}$ \\
\hline
\end{tabular}




\begin{tabular}{|c|c|c|}
\hline $\begin{array}{l}\text { Physical and non- } \\
\text { physical }\end{array}$ & $\begin{array}{l}\text { physical and non-physical. } \\
\text { Physical violence refers to the } \\
\text { destruction of properties, } \\
\text { beating up other learners or } \\
\text { educators, pushing teachers, } \\
\text { among other acts that involve } \\
\text { an outward expression of } \\
\text { emotion or anger. Non-physical } \\
\text { violence could include } \\
\text { emotional abuse, labelling, } \\
\text { suppressed anger towards other } \\
\text { people within the learning } \\
\text { environment, violent thoughts, } \\
\text { disgust, and unforgiving } \\
\text { attitudes towards others. }\end{array}$ & $\begin{array}{l}\text { assessed in various ways } \\
\text { from the physical ones we } \\
\text { see to the hidden thoughts } \\
\text { of anger some of our } \\
\text { students have towards } \\
\text { others'. }\end{array}$ \\
\hline $\begin{array}{l}\text { Subcategory: } \\
\text { Destructive }\end{array}$ & $\begin{array}{l}\text { Many participants in this study } \\
\text { expressed feelings of } \\
\text { dissatisfaction and noted that } \\
\text { they are often traumatised by } \\
\text { the spate of violence within } \\
\text { their workspace, however, } \\
\text { some of them are still very } \\
\text { resilient and believe strongly in } \\
\text { the fact that the challenges they } \\
\text { face are meant to be overcome, } \\
\text { and are part of the job. }\end{array}$ & $\begin{array}{l}\text { 'In all honesty, of recent, I } \\
\text { feel traumatised, but I } \\
\text { wake up every morning of } \\
\text { the week to come to work } \\
\text { because I believe in this } \\
\text { country and these kids. I } \\
\text { believe they are the future } \\
\text { leaders and it is my } \\
\text { responsibility to guide } \\
\text { them right as a teacher } \\
\text { irrespective of the } \\
\text { challenges I face'. }\end{array}$ \\
\hline $\begin{array}{l}\text { Category: } \\
\text { Emotional } \\
\text { Experiences }\end{array}$ & & \\
\hline $\begin{array}{l}\text { Subcategory: } \\
\text { Traumatising }\end{array}$ & $\begin{array}{l}\text { Educators narrated experiences } \\
\text { that depict fear and insecurity. } \\
\text { They no longer feel } \\
\text { comfortable at their places of }\end{array}$ & $\begin{array}{l}\text { 'How do you expect me to } \\
\text { feel safe within a place I } \\
\text { believe we are not being } \\
\text { supported appropriately as }\end{array}$ \\
\hline
\end{tabular}




\begin{tabular}{|c|c|c|}
\hline & $\begin{array}{l}\text { work and as such ignore } \\
\text { learners who they consider } \\
\text { violent. Some noted that a } \\
\text { coping mechanism is usually to } \\
\text { ignore learners who have } \\
\text { perpetrated violence because } \\
\text { engaging them at any level } \\
\text { could bring flashbacks and } \\
\text { further make them feel } \\
\text { unsettled. }\end{array}$ & $\begin{array}{l}\text { teachers? Some of these } \\
\text { learners can be very } \\
\text { violent because of the } \\
\text { gangs and groups they } \\
\text { belong to outside school. } \\
\text { If they don't touch me in } \\
\text { school, how about outside } \\
\text { school? Who will protect } \\
\text { me there? Also, some of } \\
\text { them have guidance that } \\
\text { will believe them } \\
\text { irrespective of what the } \\
\text { teachers say. The school } \\
\text { management will always } \\
\text { say teachers should } \\
\text { manage situations well, so } \\
\text { it doesn't degenerate. So, } \\
\text { who am I to turn to in } \\
\text { cases where it gets out of } \\
\text { hand? I must say, school } \\
\text { violence is very } \\
\text { traumatising and } \\
\text { disturbing'. }\end{array}$ \\
\hline $\begin{array}{l}\text { Subcategory: } \\
\text { Negative impact } \\
\text { on students }\end{array}$ & $\begin{array}{l}\text { School-based violence does not } \\
\text { have any positive influence on } \\
\text { the learners. Educators feel that } \\
\text { violence affects the learning } \\
\text { process and some learners } \\
\text { might be traumatised by just } \\
\text { experiencing violence within } \\
\text { their learning space. }\end{array}$ & $\begin{array}{l}\text { 'Violence also traumatises } \\
\text { learners. Some of them are } \\
\text { young for the kind of } \\
\text { experiences they are } \\
\text { having, and it must be } \\
\text { attended to'. }\end{array}$ \\
\hline \multicolumn{3}{|l|}{$\begin{array}{l}\text { Category: Effect } \\
\text { of Violence }\end{array}$} \\
\hline Subcategory: & $\begin{array}{l}\text { One participant mentioned that } \\
\text { aside from the injurious nature }\end{array}$ & $\begin{array}{l}\text { 'School violence is very } \\
\text { bad for school activities. }\end{array}$ \\
\hline
\end{tabular}




\begin{tabular}{|c|c|c|}
\hline $\begin{array}{l}\text { Disruption to } \\
\text { teaching and } \\
\text { learning }\end{array}$ & $\begin{array}{l}\text { of school-based violence, it is } \\
\text { also counterproductive to } \\
\text { teaching and learning. Students } \\
\text { do not learn, and even when the } \\
\text { crisis is resolved it is usually } \\
\text { very difficult to complete the } \\
\text { curriculum as catch-up } \\
\text { programmes do not always give } \\
\text { educators the opportunities to } \\
\text { deliver the material effectively. }\end{array}$ & $\begin{array}{l}\text { We're not able to teach or } \\
\text { do anything meaningful. } \\
\text { Anytime the school } \\
\text { programme gets disrupted, } \\
\text { it becomes very difficult } \\
\text { to make up for that. So, in } \\
\text { the real sense, the } \\
\text { student[s] are the ones } \\
\text { losing a lot'. }\end{array}$ \\
\hline $\begin{array}{l}\text { Subcategory: } \\
\text { Vandalism }\end{array}$ & $\begin{array}{l}\text { Violence within the school } \\
\text { environment always leaves } \\
\text { indelible marks. It ranges from } \\
\text { the destruction of property that } \\
\text { usually costs a fortune to fix or } \\
\text { replace, to the destruction of } \\
\text { some valuable school features } \\
\text { and valuables that might never } \\
\text { be replaceable. }\end{array}$ & $\begin{array}{l}\text { 'The effect of school- } \\
\text { based violence is not } \\
\text { exhaustible. It destroys } \\
\text { lives and properties. What } \\
\text { most of these violent } \\
\text { perpetrators do not } \\
\text { understand is that some } \\
\text { things they destroy are } \\
\text { irreplaceable'. }\end{array}$ \\
\hline $\begin{array}{l}\text { Subcategory: } \\
\text { Injury/Death }\end{array}$ & $\begin{array}{l}\text { School-based violence causes } \\
\text { injury and sometimes death. } \\
\text { Educators believe violence } \\
\text { within learning spaces is } \\
\text { despicable and should be } \\
\text { addressed vehemently. }\end{array}$ & $\begin{array}{l}\text { 'Educators and learners } \\
\text { get wounded and some } \\
\text { people even lose their } \\
\text { lives at events of violence } \\
\text { in school. Some of these } \\
\text { people are victims [and] } \\
\text { do not even get adequate } \\
\text { support'. }\end{array}$ \\
\hline $\begin{array}{l}\text { Category: } \\
\text { Preventive } \\
\text { Strategies } \\
\end{array}$ & & \\
\hline $\begin{array}{l}\text { Subcategory: } \\
\text { Specialised } \\
\text { training/program }\end{array}$ & $\begin{array}{l}\text { Educators mentioned that with } \\
\text { the rate at which school-based } \\
\text { violence has escalated over the }\end{array}$ & $\begin{array}{l}\text { 'Not all of my colleagues } \\
\text { are knowledgeable on how } \\
\text { to manage a situation that }\end{array}$ \\
\hline
\end{tabular}




\begin{tabular}{|c|c|c|}
\hline $\begin{array}{l}\text { mes for educators } \\
\text { on conflict } \\
\text { prevention and } \\
\text { management } \\
\text { strategies }\end{array}$ & $\begin{array}{l}\text { years, it is important that } \\
\text { teachers go through a training } \\
\text { programme to acquire relevant } \\
\text { knowledge on conflict } \\
\text { prevention and management } \\
\text { strategies, among others. }\end{array}$ & $\begin{array}{l}\text { has the potential to } \\
\text { escalate to full-blown } \\
\text { conflict. Some will even } \\
\text { tell you they do not know } \\
\text { what to do. It is therefore } \\
\text { very important that } \\
\text { [educators] constantly get } \\
\text { trained and retrained on } \\
\text { how to handle some of } \\
\text { these challenging issues'. }\end{array}$ \\
\hline $\begin{array}{l}\text { Subcategory: } \\
\text { Employing the } \\
\text { services of social } \\
\text { workers }\end{array}$ & $\begin{array}{l}\text { The aftermath of school-based } \\
\text { violence has not been taken } \\
\text { very seriously, according to } \\
\text { most educators. They opined } \\
\text { that the teachers and students } \\
\text { do not usually receive sufficient } \\
\text { help from counsellors to } \\
\text { efficiently move past this very } \\
\text { traumatic phase of their lives. } \\
\text { They reiterated that the services } \\
\text { of social workers should be } \\
\text { employed to help learners and } \\
\text { educators readjust to the } \\
\text { learning environment after the } \\
\text { outbreak of violence. }\end{array}$ & $\begin{array}{l}\text { 'Does anyone care about } \\
\text { what happens to us } \\
\text { (teachers and learners) } \\
\text { after any violence - we do } \\
\text { not get sufficient help? It } \\
\text { seems everyone forgets } \\
\text { these things are emotional } \\
\text { and psychological and it is } \\
\text { difficult to just get over it. } \\
\text { The services of social } \\
\text { workers need to be } \\
\text { engaged'. }\end{array}$ \\
\hline $\begin{array}{l}\text { Subcategory: } \\
\text { Firm disciplinary } \\
\text { measures }\end{array}$ & $\begin{array}{l}\text { Most educators believe that the } \\
\text { removal of corporal punishment } \\
\text { has made learners ruder and } \\
\text { more insolent, and as such, it } \\
\text { becomes extremely difficult to } \\
\text { correct any bad behaviour. } \\
\text { Learners are insubordinate and } \\
\text { without fear of consequence } \\
\text { they flout the school rules. } \\
\text { Most of the educators in this } \\
\text { study believe this reason has }\end{array}$ & $\begin{array}{l}\text { 'These learners are now } \\
\text { very rude, and they } \\
\text { believe they can do } \\
\text { whatever they want } \\
\text { because the teacher is } \\
\text { powerless and would not } \\
\text { be able to punish them. } \\
\text { This makes it very } \\
\text { difficult to discipline them } \\
\text { and they keep } \\
\text { misbehaving'. }\end{array}$ \\
\hline
\end{tabular}




\begin{tabular}{|l|l|l|}
\hline & $\begin{array}{l}\text { also fuelled school-based } \\
\text { violence. There is a need for } \\
\text { other firmer disciplinary } \\
\text { measures for errant learners. }\end{array}$ & \\
\hline
\end{tabular}

\section{Source: Researcher's compilation 2019}

\section{Discussion of Findings}

A safe school environment allows educators and learners to work together to reach academic goals and develop social and emotional skills. This is to say that school safety is a prerequisite for educators and learners to be able to engage in educational activities and facilitate teaching and learning (Horng, Klasik \& Loeb 2010). A school that is affected by spates of violence may find it difficult to meet the required educational goals and, as such, knowledge production becomes hampered. From the findings of this research, several factors were identified and discussed as promulgating school-based violence at the peri-urban high schools investigated. These factors are discussed below.

\section{Destabilised Family System and Modelling Violence within the Community}

Family is the most important institution in the socialisation of children in society, basically because it is their first abode. Children inherit some of the biological traits of their parents and social skills to make them productive members of society (Berns 2012). Furthermore, children adopt values, norms, and social customs from their families. The implication here is that children who are socialised around domestic violence, broken homes, or a lack of parental involvement, in general, are likely to be perpetrators of school-based violence (Pahad \& Graham 2012; Burton 2008). Apart from under-parenting, over-parenting is also identified to be a cause of violent acts (Pahad \& Graham 2012).

The prevalence of violence within most peri-urban communities in South Africa cannot be divorced from the escalating rate of school-based violence. Nconsta and Shumba (2013) argue that the nature of violence in most South African communities has contributed greatly to the rise in school-based violence, as learners end up carrying weapons to schools as a way to protect themselves due to the prevalence of violence in their communities. Incessant exposure of children to violence often moulds them and makes them receptive 


\section{Oluwatobi Joseph Alabi \& Thandanani Ngidi}

to acts of violence. Some of these learners come from broken homes and homes prone to domestic violence, and in such cases, learners need a proper role model who can redirect their interest from the one prevalent within their homes and communities.

A school does not operate within a vacuum; it is part of the broader society or community in which it is situated. This, therefore, speaks to the fact that eminent social facts within the community affect the dynamics of schoolbased violence. Learning spaces reflect the ideals and values of society at large. Medina (2010) argues that children from dysfunctional communities where high levels of crime occur often become involved in drug and alcohol abuse, violence and use of illegal firearms, and they are most likely to take part in school-based violence. Not only do these factors increase the chances of their involvement in crime and violence, it also increases the vulnerability of educators working in such communities.

Some educators revealed that social workers are needed in schools to provide counselling and support to learners. It is believed that this reformative process yields more positive results rather than just punishing learners when they do something wrong. The work of a social worker will be to address the fundamental factors that make learners susceptible to embracing violence. These learners need someone to listen to their problems, because most of them do not get attention at home, and as such the role of a social worker becomes particularly important. Straus, Gelles and Steinmetz (2017) argue that individuals who have a history of being abused either by family members or other members of society are likely to become violent towards others, especially if they are teenagers. It is important to provide support systems that will help learners to relieve their anxiety from these experiences. Substance abuse emerged as a major precipitating factor for perpetrating violence against others.

\section{Alcoholism and Drug Consumption}

Most educators believe that violent attacks on educators occur because of an increased rate of alcohol and drug abuse among learners. Substance abuse is one of the most common, if not the leading, cause of violence among the youth in South Africa (Modisaotsile 2012). Access to illegal substances is the source of blatant forms of violence directed at figures of authority such as educators and principals of schools. Burton's (2008a) research also indicates that $58.1 \%$ of educators at secondary schools report feeling unsafe at their schools when 
teaching because of the behaviour learners exhibit after consuming some of these substances. According to a study on educators' responses to school violence in Cape Town, participants reported several symptoms of social and psychological distress, shame, guilt, lack of assertiveness, anger, power-lessness, feeling blamed by others, and withdrawal from others as common symptoms of drug and alcohol abuse (Shields et al. 2014). It is disruptive when educators must deal with coordinating classroom activities and manage the relapsing behaviour of learners who abuse drugs. The aftermath of the aforementioned common traits is that learners quickly become irritated with extraordinarily little provocation and there is an outburst of chaos within the classroom. It is therefore, important that the educator takes up a counselling role to manage these types of behaviours before they escalate into violent acts.

\section{Gangsterism}

Gangsterism is a serious social menace globally. It is reported that youth gang activities have been linked to various crimes within secondary schools, and the presence of these gangs has also increased the abuse of substances (Mncube \& Madikizela-Madiya 2014). Furthermore, schools with prevalent gang activities are also more susceptible to intense school violence. The findings from this study unveiled that the presence of gangs within secondary schools is a bane to the peace and tranquillity of these learning spaces. Educators believe that these gangs are often a reflection of the structural and sociocultural decay within the society and it puts everyone within the school environment in danger. Crawage (2005) argues that gangs within schools should be perceived as part of the problems eminent in South African society. This is a reflection of the anomic conditions which our communities have fallen into, where learners and youth challenge and dismiss legitimate authority. Gangs emerge from communities often because of the socio-economic apertures of the society (Mncube \& Madikizela-Madiya 2014). These apertures include unemployment, poor living conditions, low income, unemployment, poverty, and deprivation.

\section{Ineffective Disciplinary Measures within Schools}

Narratives from educators suggest that banning corporal punishment and the lack of effective alternatives have exacerbated the rate and the nature of crimes and violence in secondary schools. This aggravates the lack of discipline that 


\section{Oluwatobi Joseph Alabi \& Thandanani Ngidi}

exists in public schools and harms both learners and educators. Kruger and Van Schalkwyk (1993) argue that a schooling environment with little or no order can lead to the decay of the teaching and learning culture. It becomes impossible to get any work done in an environment filled with constant disruptions. Furthermore, Mncube and Harber (2013) argue that exposure to school violence could result in serious long-standing physical, emotional and psychological implications for both educators and learners, which includes symptoms of distress, reduced self-esteem, a risk of depression and suicide, reduced school attendance, impaired concentration, fear, and a diminished ability to learn. Educators and learners perform best in an environment that is organised and safe. The principal and educators must maintain order and discipline in a school and, to do that, there must be a written code of conduct that applies to both educators and learners to ensure that the school operates smoothly. Sometimes it becomes difficult for educators to enforce discipline in an environment in which they feel unsafe. Unstable discipline in schools affects the learning environment negatively and results in a low pass rate at these particular schools. According to the educators, when the laws and codes of conduct that are meant to regulate behaviour within the school are perceived to, or actually do lack the stringent measures to reprimand deviance, they become weak and ineffective. Consequently, indiscipline becomes the norm. This is a brief description of the situation in most South African violence ridden secondary schools as narrated by the educators in this study. Educators believe that the eradication of corporal punishment without an equivalent alternative has produced a new breed of learners who are undisciplined and who disregard instructions without fear of repercussion. While the eradication of corporal punishment has left a disciplinary gap, educators and school managements must think of innovative ways to ensure conformity and compliance rid of violence or any form of abuse.

\section{Understanding the Dynamic Nature of Violence Within the Selected Secondary Schools}

School-based violence is prevalent at the selected secondary schools in this study. However, the prevalence of this school violence is manifested in both physical and non-physical forms. Irrespective of the form, it is a menace that is psychologically and physically destructive. Common types of violence within these schools includes assault - physical or sexual robberies, rape, murder, 
sexual harassment, intimidation bullying, shootings, stabbings, theft of property, and vandalism. Literature establishes that the common types of violence within South African secondary schools, span through mental/ psychological to physical forms of violence (Burton 2008b; Jefthas \& Artz 2007).

Ncontsa and Shumba (2013) opine that acts such as bullying, corporal punishment, vandalism, gangsterism and sexual harassment are some of the most prevalent violent acts in South African schools. Other forms of violence identified include discrimination, drug dealing, smoking, gossiping and the use of vulgar language. Ncontsa and Shumba (2013) note that bullying is the most common form of school-based violence. Bullies harass and beat other learners, take their possessions, such as lunch money, and this becomes very traumatising for the victimised learner (Ncontsa \& Shumba 2013). The need for power and control results in bullying where young learners and the ones who are powerless are the victims. It also became evident from the narratives of the educators in this study that school-based violence, inasmuch as it is learner-based, is also educator-centred. At the forefront of dealing with violence in schools are the educators, hence, they form a major part in the narrative of school-based violence, especially in South Africa.

South Africa is currently faced with high levels of crime-related violence that seems to increase annually and involves a lot of the youth (Mattes 2012). Incidences of crime-related violence are often associated with the easy access young people have to drugs, weapons, and gang membership. Thus, educators are often required to go for training or workshops where ideas are shared, and various remedial strategies are discussed on how to address school violence. However, some of these measures and procedures which they are taught have not been effective in curtailing the school-based violence (Bester $\&$ Du Plessis 2010). Educators mention that school-based violence is a menace that challenges the education profession, because educators are trained to teach and yet they have to assume the roles of policemen, social workers and nurses whenever incidences of violence erupt in schools. The burden on educators' shoulders is therefore increased as they must perform the tasks of other professionals for which they are rarely or inadequately trained. As it becomes more glaring that school-based violence is a serious social menace disrupting teaching and learning, it is important to approach the situation holistically. Addressing the escalating rate of school violence will require that social workers, psychologists, sociologists, parents, educators, and other stakeholders within society work together. 


\section{Effects of School-based Violence}

The prevalence of school-based violence breeds several consequences, and of significant importance is the emotional and physical impact it has on both educators and learners. Some of these impacts are discussed below.

\section{Trauma}

Bester and Du Plessis (2010) report an incident in Durban where a group of boys from a school allegedly raped another student on the school premises during school hours. Bester and Du Plessis note that a video was allegedly taken by one of the boys involved, which came to the attention of the police after an educator had seen the video and reported it. These boys were arrested and later released in the custody of their parents. This is an example of one experience that produces serious trauma in the life of the victim. Interestingly, this case is just one of several that go unreported; it is an indication of how weak our value system and sense of morality have become as a society. Educators in this study noted that acts of violence in its varying forms within the school environment are traumatising and exceedingly difficult to deal with.

\section{Disruption of the Learning and Teaching Culture}

According to Burton (2008a), there is increasing concern in South Africa that primary and secondary schools are becoming sites of widespread violence. While schools are meant to be a safe haven for knowledge production, teaching and learning, school-based violence is turning South African schools into a battlefield ravaged by insecurity and normlessness. Griggs (2002) notes that school-based violence is not a new phenomenon to South Africa; however, what is becoming evident is the increasingly serious nature of the violence. For example, the common types of violence have shifted from cases of bullying to more serious forms of victimisation that could result in maiming and death.

Ncontsa and Shumba (2013) mention that school-based violence is very disruptive, as it affects the teaching and learning in schools. Educators cannot carry out their responsibilities effectively in an environment that is uncontrollable, unmanageable, and ill-disciplined because of violent acts. Due to violence, educators are demotivated to teach, and their morale becomes low when being met by empty classes because learners leave school earlier than the stipulated time. It is also difficult to complete a syllabus at schools with high 
rates of violence, because most of the time is spent on preventing or resolving violence rather than on teaching. Vandalism as another form of school-based violence has resulted in a lack of textbooks and other teaching materials, thus making teaching exceedingly difficult for the educators. In-fighting caused by the lack of respect of learners towards one another creates a tense atmosphere in the classroom and it affects the learners' concentration levels. It is important to acknowledge that learners are not the only ones in schools who may experience bullying and victimisation. Educators narrated that they are also adversely affected by this violence. Educators also become victims of violence; they fear for their own lives, which makes them go to classes unprepared and in constant fear for their safety.

\section{Injury/ Death}

Some crimes perpetuated within some of these school environments go beyond assault and bullying. Some of these profoundly serious crimes include inflicting injuries on a victim and in some cases even death. Educators revealed that most of these acts are usually carried out by gangs. Gang membership fulfils learners' psychological needs since it makes them feel a sense of acceptance and belonging. It also enhances their social status, especially for those learners who see themselves as unpopular and powerless. Learners who belong to gangs are promised protection, power, status, sexual and social excitement and valued incentives. The male members of such gangs go to extreme lengths to protect their membership status, even if it requires of them to commit violent acts (Miller \& Kraus 2008). Within these gangs, there is strength in numbers when fights break out, and gangs compete to recruit as many learners from schools as possible. Ownership of weapons such as knives and guns are a symbol of power among gang members, and this further leads to a dangerous form of violence in schools. Mncube and Harber (2011) report that most learners are coerced into joining gangs, and because of the already established fear of insecurity within the school and community they feel compelled to join in. The growth of gangs within the school environment has further heightened the rate and nature of violence as some of these gangs are equipped with extremely dangerous weapons that can maim and even kill.

\section{Preventive Strategies}

Some of the recommendations discussed in this section have been identified as 
essential for curbing or reducing the spate of school-based violence within South African high schools.

\section{Specialised Training/Programmes for Educators on Conflict Prevention and Management Strategies}

As lack of discipline becomes more prevalent at some of these schools, educators must be equipped to handle the various forms of behaviour that will be exhibited by some learners who might not conform to the tenets of the school. Acquiring proper and relevant conflict management and resolution skills will not only help to manage the outburst of school-based violence within the schools, but it will also diffuse tension or potential situations that could escalate into full-blown conflict, beforehand. Spotting situations that could escalate into school-based violence, both within and outside the classroom, is an especially important skill that educators should possess. As such, school managements and government must invest in training and retraining of educators to acquire these relevant skills.

\section{Employing the Services of Social Workers and Psychologists}

Educators in this study expressed a need for counselling services as a way of helping them deal with the effects of violence, and to help the learners get psychological support. Some educators had to use their own funds to obtain professional help, which can be costly. It is therefore recommended that support services regularly be made available by the Department of Education to traumatised educators and learners.

\section{Firm Disciplinary Measures}

In trying to maintain discipline, educators always need to worry about being targeted by the learners, and they also have to be very cautious that they are not accused of child abuse (Singh 2006). Most educators believe that parents may condone the use of corporal punishment on their children, but learners are well aware of their rights and there is little that educators can do to enforce conformity within the schools since corporal punishment is outlawed. According to Singh (2006: 26), resistance to 'the idea of learners being given 
power without being taught responsibility has strongly gained momentum, they are more aware of their rights and less aware of their responsibilities'. The study also found that most educators believe that the School Governing Body (SGB) and the school committee in charge of discipline and security are doing the best it can to curb school-based violence against educators; however, it is less effective without putting some constraints on the learners' behaviour. Nevertheless, the majority of the educators from the sampled schools believe that the Department of Basic Education and the community are not doing enough to assist schools in their management of school-based violence, since effective alternative methods of ensuring conformity have not been introduced.

\section{Conclusion}

The menace of school-based violence in South Africa might be difficult to eradicate or abate if the growing spate of violence and crime within host communities are not addressed. South African communities are characterised by a high rate of crimes and violence, as such, gangs start from the community and move into schools. Children see how their elders carry weapons and emulate this behaviour. In the same manner domestic violence has left children traumatised, thus making them violent. These factors have contributed to the pre-valence of violence in schools and require urgent attention. Various sociopsychological support systems must be provided for educators and learners. Even though learners are always involved in these violent acts, in some cases educators have been identified to be perpetrators and also victims of these violent acts. Implicatively, the menace of school-based violence is complex and involves all stakeholders within the school environment. Irrespective of role (learner or educator), it is possible to be a perpetrator or a victim of schoolbased violence. It is evident from the educators' narratives that managing violence in schools requires a multi-level approach that not only addresses the behavioural issues of, but also take cognisance of the social pathology of the society. Accordingly, developing a safer school environment requires the participation of all stakeholders - learners, educators, the School Management Team (SMT), School Governing Board (SGB), parents, and the community at large.

Cooperation between educators and parents should be enforced, because educators find it difficult to train and discipline learners without receiving cooperation from parents. Parents should be informed about the 
importance of getting involved in their children's academic affairs. They are to show up whenever the educators request their presence, and they should frequently seek to know about the progress of their children. Educators and parents should work together, as their unity will help win the fight against school-based violence.

\section{References}

Banks, J.A. 2014. Diversity, Group Identity, and Citizenship Education in a Global Age. Journal of Education, 194,3: 1 - 12. https://doi.org/10.1177/002205741419400302

Barbarin, O.A. \& L.M. Richter 2001. Mandela's Children: Growing Up in Post-apartheid South Africa. New York, NY: Routledge.

Berns, R. 2012. Child, Family, School, Community: Socialization and Support. Belmont, CA: Wadsworth Cengage Learning.

Bester, S. \& A. du Plessis 2010. Exploring a Secondary School Educator's Experiences of School Violence: A Case Study. South African Journal of Education, 30,2: 203 - 229.

https://doi.org/10.15700/saje.v30n2a340

Burton, P. \& Leoschut, L., 2013. School Violence in South Africa. Results of the 2012 National School Violence Study, Centre for Justice and Crime Prevention, Monograph series, 12.

Burton, P. 2008a. Experience of School Violence in South Africa. Centre for Justice and Crime Prevention (Monograph Series, No 4). Cape Town. CJCP Monograph No. 3, Cape Town, 37.

Burton, P. 2008b. Merchants, Skollies and Stone. Experience of School Violence in South Africa. Centre for Justice and Crime Prevention, Monograph Series, No 4.

Centre for Justice and Crime Prevention. 2016. http://www.cjcp.org.za/

Crawage, M. 2005. How Resilient Adolescent Learners in a Township School

Cope with Violence: A Case Study. PhD thesis. Johannesburg: University of Johannesburg.

Creswell, J.W. \& J.D. Creswell 2017. Research Design: Qualitative, Quantitative, and Mixed Methods Approaches. California: Sage Publications.

Dawes, A., C. Tredoux \& A. Feinstein 1989. Political Violence in South Africa: Some Effects on Children of the Violent Destruction of their Com- 
Community. International Journal of Mental Health 18,2: 16 - 43. https://doi.org/10.1080/00207411.1989.11449122

De Wet, C. 2010. Victims of Educator-targeted Bullying: A Qualitative Study.

South African Journal of Education 30,2: 190 - 202.

https://doi.org/10.15700/saje.v30n2a341

Du Plessis, A.H. 2008. Exploring Secondary School Educator Experiences of

School Violence. Doctoral dissertation, University of Pretoria.

Fiske, S.T., M. Moya, A.M. Russell \& C. Bearns (eds.). 2012. Facing Social

Class: How Societal Rank Influences Interaction. New York: Russell

Sage Foundation.

Griggs, R. 2002. Preventing Crime and Violence in South African Schools: A

Review of Learning and Good Practice from Eight Interventions. Criminal

Justice Initiative, Open Society Foundation for South Africa.

Horng, E.L., D. Klasik \& S. Loeb 2010. Principal's Time Use and School

Effectiveness. American Journal of Education 116,4: 491 - 523.

https://doi.org/10.1086/653625

Jefthas, D. \& L. Artz 2007. Youth Violence: A Gendered Perspective. In

Burton P. (ed.): Someone Stole my Smile: An Exploration into the Causes

of Youth Violence in South Africa. CJCP Monograph 3, Cape Town, 7.

Kruger, A.G. \& O.J. van Schalkwyk 1993. Classroom Management. Pretoria: Academica.

Liang, H., A.J. Flisher \& C.J. Lombard 2007. Bullying, Violence, and Risk Behavior in South African School Students. Child Abuse and Neglect 31:

161 - 171. https://doi.org/10.1016/j.chiabu.2006.08.007

PMid:17313977

Mathews, S. \& P. Benvenuti 2014. Violence against Children in South Africa:

Developing a Prevention Agenda. In Mathews, S., L. Jamieson, L. Lake

\& C. Smith (eds.): South African Child Gauge 2014. Cape Town, South Africa: Children's Institute, University of Cape Town.

Mattes, R. 2012. The 'Born Frees': The Prospects for Generational Change in Post-apartheid South Africa. Australian Journal of Political Science 47,1: $133-153$.

https://doi.org/10.1080/10361146.2011.643166

Medina, C. 2010. 'Reading across Communities' in Biliteracy Practices: Examining Trans-local Discourses and Cultural Flows in Literature Discussions. Reading Research Quarterly 45,1: 40 - 60.

https://doi.org/10.1598/RRQ.45.1.3 
Miller, T.W. \& R.F. Kraus. 2008. School-related Violence: Definition, Scope, and Prevention Goals. In Miller, T.W. (ed.): School Violence and Primary Prevention. New York: Springer.

https://doi.org/10.1007/978-0-387-77119-9_2

Mncube, V. \& C. Harber 2011. The Dynamics of Violence in South African Schools. Report. University of South Africa.

Mncube, V. \& N. Madikizela-Madiya 2014. Gangsterism as a Cause of Violence in South African Schools: The Case of Six Provinces. Journal of Sociology and Social Anthropology 5,1: 43 - 50.

https://doi.org/10.1080/09766634.2014.11885608

Modisaotsile, B.M. 2012. The Failing Standard of Basic Education in South Africa. Policy Brief 72: 1 - 7.

Mouton, J. 2001. How to Succeed in your Master's and Doctoral Studies: A South African Guide and Resource Book. Hatfield, Pretoria: Van Schaik. Ncontsa, V.N. \& A. Shumba 2013. The Nature of Causes and Effects of School

Violence in South African High Schools. South African Journal of Education, 33,3: 1- 15.

https://doi.org/10.15700/201503070802

Neser, J.J. 2006. The Prevalence of School Violence and the Impact on Victimised Learners: An Exploratory Study. Child Abuse Research South Africa: A South African Journal 7,1: 31 - 47.

http://hdl.handle.net/10520/EJC24304

Ngqela, N. \& A. Lewis 2012. Exploring Adolescent Learners' Experiences of School Violence in a Township High School. Child Abuse Research: A South African Journal 13,1: 87 - 97.

http://www.andrewlewis.co.za/Ngqela Lewis.Township.Violence.Carsa. pdf

Pahad, S. \& T.M. Graham 2012. Educators' Perceptions of Factors Contributing to School Violence in Alexandra. African Safety Promotion Journal 10,1: 3 - 15.

Prinsloo, J., 2008. The Criminological Significance of Peer Victimisation in Public Schools in South Africa. Child Abuse Research in South Africa 9,1: 27 - 36.

Republic of South Africa [RSA] 1996. Constitution of the Republic of South Africa, Act 108 of 1996. Pretoria: Government Printer.

Schwandt, T.A. 2014. The Sage Dictionary of Qualitative Inquiry. Los Angeles: Sage Publications. 
Shields, N., K. Nadasen \& C. Hanneke 2015. Teacher Responses to School Violence in Cape Town, South Africa. Journal of Applied Social Science 9,1: $47-67$.

https://doi.org/10.1177/1936724414528181

Shields, N., K. Nadasen \& L. Pierce 2008. The Effects of Community Violence on Children in Cape Town, South Africa. Child Abuse \& Neglect 32,5:

589 - 601. https://doi.org/10.1016/j.chiabu.2007.07.010

PMid:18511114

Simpson, M.A. 1993. Bitter Waters: Effects in Children of the Stresses of Unrest and Oppression. In Wilson,J.P. \& B. Raphael (eds.): International Handbook of Traumatic Stress Syndromes. New York, NY: Plenum. https://doi.org/10.1007/978-1-4615-2820-3_51

Singh, S.K. 2006. Violence in Schools: A Recipe for Disaster. MA dissertation, University of KwaZulu-Natal, Durban.

Stevens, G., G. Wyngaardt \& A. van Niekerk 2001. The Safe School Model: An Antidote to School Violence? Perspectives in Education 19,4: 137 149.

Straus, M.A., R.J. Gelles \& S.K. Steinmetz 2017. Behind Closed Doors: Violence in the American Family. Routledge.

https://doi.org/10.4324/9781351298681

Taole, M.J. \& M. Ramorola 2014. Teacher Attitudes, Professionalism and Unprofessionalism in Relation to School Violence. The Journal of Sociology and Social Anthropology 5,1: $19-27$.

https://doi.org/10.1080/09766634.2014.11885605

Terre Blanche, M. \& K. Kelly 1999. Interpretive Methods. Research in Practice: Applied Methods for the Social Sciences 123 - 146.

United Nations Educational, Scientific and Cultural Organization [UNESCO]. 2017. School Violence and Bullying: Global Status Report. Paris, France: UNESCO.

http://unesdoc.unesco.org/images/0024/002469/246970e.pdf

Van Jaarsveld, L., 2008. Violence in Schools: A Security Problem?. Acta Criminologica: African Journal of Criminology \& Victimology Sed-2: 175-188.

Oluwatobi Joseph Alabi Department of Sociology University of Johannesburg damilarealabi40@yahoo.com 
Oluwatobi Joseph Alabi \& Thandanani Ngidi

Thandanani Ngidi Department of Criminology and Forensics University of KwaZulu-Natal Durban ricotee94@gmail.com 